\title{
19
}

\section{Civic Crowdfunding: Four Perspectives on the Definition of Civic Crowdfunding}

\section{Karsten Wenzlaff}

\section{Introduction}

Civic crowdfunding is a subset of crowdfunding practices which is increasingly covered both in academic literature and practitioners' reports. The term 'civic crowdfunding' (civCF) describes the financing of projects dedicated to a 'civic' purpose, initiated by 'civic' initiatives, supported by individuals and organizations with 'civic' intentions, and (often) intermediated on online platforms which dedicate themselves to 'civic' purposes and stakeholders. The term 'civic' itself can refer to the actions of and within cities or municipalities, but also to the actions of citizens towards a common goal (Wenzlaff 2020).

CivCF projects cover a wide range of topics. Financing public bridges and streets, public beaches, gardens, playgrounds, theatres, museums, festivals and events, (non-profit) media, science, health institutions,

K. Wenzlaff $(\bowtie)$

Faculty of Business, Economics, and Social Sciences, University of Hamburg, Chair Digital Markets, Hamburg, Germany

e-mail: karsten.wenzlaff@uni-hamburg.de 
political campaigns, and monuments have been placed on platforms dedicating themselves to civCF or within-'Community' categories on platforms dedicated to broader purposes.

The civCF literature is limited but has been growing in recent years. The aim of this chapter is to shed light on the state of civCF research and to expand the definition of civCF as a contribution to future research. CivCF practices are explained through the perspective of the project, the initiators, the supporters, and the platform. The need to analyse civCF through this fourfold-perspective stems from an inadequate definition based on any one of the perspectives. The literature, as is being discussed in the "Definition and Perspectives of Civic Crowdfunding" section, tends to focus only on the project, only on the supporter, only on the project owner, or only on the platform. The contribution of this chapter is to bring these four perspectives together and show how they complement each other.

The method used in this chapter is a narrative literature review (Onwuegbuzie and Frels 2016), with the aim to reflect upon literature which has advanced the debate on civic crowdfunding, supported by twenty short examples of civic CF projects or platforms. For this purpose, fifty-four academic publications (journal articles, book chapters, working papers) and six non-academic practitioners' guidebooks were analysed, which were identified through searching for 'Civic Crowdfunding' on Google Scholar and Web of Science.

The structure of the chapter is as follows: the "Development of Civic Crowdfunding" section discusses the development of civCF. The "Definition and Perspectives of Civic Crowdfunding" section compares definitions of civCF and develops four perspectives, which are then elaborated in the "Perspective 1: Project", "Perspective 2: Supporter", "Perspective 3: Owner", and "Perspective 4: Platform" sections. These are followed by a research agenda and practical implications in the "Conclusion" section. 


\section{Development of Civic Crowdfunding}

Civic crowdfunding is an old phenomenon. In the late nineteenth century, cultural institutions in the expanding cities were crowdfunded in the sense that cooperatives financed the building of theatres, parks, and swimming facilities.

The financing of the often-quoted Pedestal of the Statue of Liberty at the end of the nineteenth century in New York can be classified as a civCF campaign since it financed a public memorial. Even earlier examples of civCF are the publication of the newspaper 'Wandsbecker Mercurius' in 1745 which was financed through a pre-purchase subscription model.

With the advent of the internet, civCF campaigns were increasingly hosted on crowdfunding platforms (CFPs). An overview of civCF platforms is given in Table 19.1. The vast majority of civCF campaigns are hosted on donation-based CFPs, for instance, the purchasing of the Tasman Beach by the public in New Zealand was hosted on the donationbased platform GiveALittle (Boyle 2016; Doan and Toledano 2018). Civic crowdfunding campaigns can also be found on reward-based crowdfunding CFPs, with both tangible and non-tangible rewards, such as the campaign to bail out the Greek people during the debt crisis (Indiegogo 2015).

Table 19.1 Overview and typology of civic crowdfunding platforms (selection)

\begin{tabular}{|c|c|c|}
\hline & $\begin{array}{l}\text { Donation- and reward- } \\
\text { based CFPs }\end{array}$ & $\begin{array}{l}\text { Equity- and lending-based } \\
\text { CFPs }\end{array}$ \\
\hline $\begin{array}{l}\text { All-purpose CFPs } \\
\text { with civCF } \\
\text { project } \\
\text { category }\end{array}$ & $\begin{array}{l}\text { International CFPs: } \\
\text { GoFundMe, Kickstarter, } \\
\text { Indiegogo } \\
\text { Local CFPs: Startnext, } \\
\text { Wemakeit, } \\
\text { Kisskissbankbank, } \\
\text { Produzioni Dal Basso }\end{array}$ & \\
\hline $\begin{array}{l}\text { Special-purpose } \\
\text { CFP dedicated } \\
\text { to civCF }\end{array}$ & $\begin{array}{l}\text { International CFPs: } \\
\text { Spacehive } \\
\text { Local CFPs: Ioby, } \\
\text { Voorjebuurt, Place2Help }\end{array}$ & $\begin{array}{l}\text { International CFPs: Ethex, Kiva } \\
\text { Local CFPs: CommunityShares. } \\
\text { org.uk, } \\
\text { LeihDeinerUmweltGeld }\end{array}$ \\
\hline
\end{tabular}


Campaigns are also hosted on few equity-based CFPs and lendingbased CFPs (Assenmacher 2017; Catapult 2018; Wenzlaff et al. 2015; Old et al. 2019). The civic equity-based crowdfunding platform "LeihDeiner-Stadt-Geld" (Lend money to your city) is facilitating equity investments in city property, such as an investment into firearms equipment at the city of Oestrich-Winkel (LeihDeinerStadtGeld GmbH 2012).

Civic crowdfunding campaigns can be found on special-purpose CFPs, with Spacehive being the most prominent international example. Italy, France, the Netherlands, the UK, Germany, and many other countries have seen platforms dedicated to civic crowdfunding, with a majority of platforms offering donations and pre-sales of rewards. Almost all major international reward-based platforms (like Kickstarter, Indiegogo, GoFundme) and many local reward-based platforms have introduced project categories focussing on civil purposes (Davies 2014). The German platform 'startnext', in its category called 'Community', featured projects such as the funding of a fountain in a Berlin Park or the Pacific Garbage Screening Project (Förderkreis des FEZ-Berlin e.V. 2018; PGS-Team 2018). The Italian platform Produzioni Dal Basso is an all-purpose CFP which features the category of 'Social and Community', making up 1145 projects (of 5771 projects in total) and EUR $3.6 \mathrm{~m}$ (of $11.4 \mathrm{~m}$ in total) and thus constituting the biggest category on the platform.

It is interesting to reflect on the interaction between all-purpose CFPs and special-purpose CFPs. The history of platform-based crowdfunding cannot be summarized in this chapter, but with regard to civCF, it should be noted that the first reward-based platforms were special-purpose CFPs dedicated to music and film (Sellaband, Artistshare) which gave rise to all-purpose platforms (Kickstarter, Indiegogo). The success of platforms like Kickstarter and Indiegogo influenced the founding of special-purpose civCF platforms, which in turn motivated the large all-purpose platforms to introduce civCF categories. In equity-based and lending-based crowdfunding, the special-purpose CFPs developed alongside special-purpose CFPs for start-ups, energy projects, or real estate projects. However, international equity-based crowdfunding platforms like OurCrowd do not have a dedicated category to civCF campaigns.

Analysing the interaction between civCF platforms and civCF categories on all-purpose CFPs merits further research since it would provide a 
narrative for the self-framing of civCF campaigns, which in turn informs their choice of a platform (Lee et al. 2019). There is anecdotal evidence that all-purpose CFPs dedicated to creative industries introduced civCF campaigns categories because of repeated requests to host civCF campaigns, sometimes by project initiators which used the CFP for projects such as funding games, movies, and music albums, and then aiming to use their existing community on the platform to initiate projects with a civic purpose. For instance, the owners of the sustainable condom factory Einhorn used the crowdfunding platform 'startnext' in Germany for funding their business, then proceeded to use the same platform for financing a 'democracy festival' to combat climate change (Einhörnchen 2015; Olympia 2020).

Civic crowdfunding campaigns are not restricted to platforms, as is being discussed in the "Perspective 4: Platform" section. Some of the significant campaigns which received widespread attention in the literature, such as the Luchtsingel Bridge in Rotterdam (Youngwoo 2019) or the funding of statutes by the Louvre Museum (Izzo 2017), were not hosted on platforms, but on newly created websites for the duration of hosting the campaign.

\section{Definition and Perspectives of Civic Crowdfunding}

The definition of civCF is not consistent across the literature. This paper identifies four perspectives which are taken as per the different units of analysis: (1) the project, (2) the supporters, (3) the project owners, and (4) the platform (CFP) which hosts the campaign.

One of the first definitions of civCF was very narrow. Barollo and Castrataro posited that civCF takes place outside of public budgets: civCF is the "collective funding of public works and projects-outside the budget of the interested entity or administration-collected by citizens, organisations and private companies sometimes in match funding with the administrations themselves" (Barollo and Castrataro 2013; Oliva 2018; Colasanti et al. 2018). The dichotomy between campaigns 
which are contributing towards a public budget and campaigns that function outside of public budgets is seldom explicitly discussed in the literature, but present in the different perspectives discussed below. Since that early definition, the overwhelming majority of academic researchers have argued that civCF is characterized by being neither inside nor outside the public budgets, but interacts positively and negatively with public budgets, for instance, both by supplementing public budgets and by highlighting underfunded public services.

Another very narrow definition of civCF suggests it is "the collaborative funding of public infrastructure" (Wenzlaff et al. 2015; Wenzlaff 2017). This definition restricts civCF to immobile, permanent, and public artefacts and institutions. It excludes campaigns for public events, festivals, or civic activism as not being part of civCF in the narrow sense. In this definition, collaboration distinguishes civic crowdfunding from other forms of public fundraising for infrastructure (such as municipals bonds, social impact bonds), supporters can observe each other's actions on the crowdfunding platform and thus coordinate their behaviour indirectly (Nielsen 2018).

This chapter proposes to move beyond these two dichotomies by identifying similarities of four perspectives in civCF.

The project perspective is taken when defining civCF "as the practice applied to civic projects" (Doan and Toledano 2018). Civic projects are projects related to the duties or activities of people in their town, city, or local area. The supporter and project perspective are combined when defining civCF as "the process of raising funds from a large pool of interested agents [...] when applied for the provision of public projects" (Damle et al. 2019).

The perspective of the supporters is found in a definition of civCF which "borrows principles from both private crowdfunding and grassroots community organisation by enabling citizens to develop community projects that are funded by donations through an online platform" (Brent 2017).

The perspective of the project owner is taken when civic crowdfunding is defined as "projects that benefit from government assets, funds and sponsorship for the acquisition and development of future public assets" (Hummel 2016), therefore necessitating the involvement of government in the delivering or implementation of the crowdfunding campaign goal. 
The perspective of the platform is used when a civic crowdfunding platform is defined as "a type of platform dedicated to fundraising for issues of public concern" (Desmoulins and Charbit 2017), connecting it to both the government involvement and community projects.

In the following sections, the chapter proceeds to discuss each of the four perspectives of civCF in detail. The project perspective is discussed through its outcome, geographic or demographic scope. The supporter perspective is discussed through the motivation and actions of supporters. The project owner perspective relates to the legal status of the project owner and the associated benefits. The platform perspective discusses the geographic area, type of crowdfunding, functionalities, and constraints within the crowdfunding platform.

\section{Perspective 1: Project}

Civic crowdfunding can be seen through the lens of the crowdfunding campaign or the project which is being funded. Academic research uses parks, playgrounds, and gardens as unambiguous examples of civCF (Porter and Veenswijk 2018). Would it suffice to simply allow the projects to decide whether they are part of civCF?

No, because on many all-purpose CFPs the distinction between civCF projects and other, more entrepreneurial projects, is not clear-cut. Three examples are given below.

Indiegogo, one of the largest reward-based CFPs globally, allows projects to be placed in the category "Community Projects—For good neighbors everywhere” (Indiegogo 2019b).

The three most-funded projects in this category are indicative of the diverse field of campaigns labelled with civic crowdfunding. 'Stone Groundbreaking Collaborations' received USD $2.5 \mathrm{~m}$ to create a new line of craft beer pubs. Its placement in the 'Local Businesses'-subcategory 
indicates it could also be classified as entrepreneurial reward-based crowdfunding campaign. The second-highest community project is the 'Greek Bailout Fund', which raised EUR 1.9m for supporting the Greek population during the debt crisis in 2015. The all-or-nothing goal set the campaign at EUR 1.6b, thus making the campaign unsuccessful despite support from 108.631 people. The third-highest campaign 'Restore the Shore' raised USD $1 \mathrm{~m}$ for the restoration of a New Jersey beach. The campaign goal was only reached by $84 \%$; however, since Indiegogo also allows keep-it-all (flexible funding) campaigns, the funds were distributed to the cause (Indiegogo 2012, 2015, 2016).

These three examples are all part of the civCF category on Indiegogo but would not necessarily fall into a project-based definition of civCF.

CivCF campaigns should provide a service to a community, either replacing and enhancing existing service to a community (Davies 2014; Stiver et al. 2015) or initiate a new service to citizens (Miglietta and Parisi 2017).

By improving public services, a civCF project provides a participatory culture and enables citizens to interact with government officials, thus impacting government policies (Bonini and Pais 2017). CivCF can provide better participation in urban planning (Brent 2017; Miglietta and Parisi 2017; Shareable 2018; Brandmeyer 2015; Kukla 2014; van Veelen 2015; Sedlitzky and Franz 2019) by using resources more efficiently due to the participatory planning process, which benefits both the supporters as well as the project owners, if project owners are also public entities. As it is being discussed in the "Perspective 2: Supporter" and "Perspective 3: Owner" sections, a distinguishing element of civCF projects is that the project goals are both in the interest of supporters and project owners.

The provision of a public good is essential to a civic crowdfunding campaign, especially in economic analysis (Davies 2014; Hummel 2016; Brent 2017). A public good (as can be seen in Table 19.2) is characterized

Table 19.2 Typology of goods

\begin{tabular}{lll}
\hline & Excludable & Non-Excludable \\
\hline Rivalrous & Private good & Club good \\
Non-rivalrous & Commons & Public good \\
\hline
\end{tabular}


by the fact that users cannot be excluded. Its usage is non-rivalrous- the usage of one user does not reduce the utility for another of that good for another user (Samuelson 1954).

Such a narrow definition would effectively eject many campaigns from the definition of civCF. Davies (2014) notes that goods provided by civCF campaigns can be both semi-rivalrous and semi-excludable. For instance, a public bike service is semi-rivalrous because each bike hired by a user is not available for any other user at that particular time, but the general service is available at other times. A civCF campaign for a health infrastructure is semi-excludable since it would not preclude the operator from charging for his services, but at the same time would provide access to citizens to these services (Zhang et al. 2019).

Even excludable-non-rivalrous goods (termed "club good") can be considered as being inside definition of civCF (Desmoulins and Charbit 2017). Crowdfunding a public museum (without entry) would create a public good (Simeoni and De Crescenzo 2018), crowdfunding a private museum would create a club good. The private museum can set exclusion mechanisms (entry prices, access), the art displayed in the museum is characterized by non-rivalrous usage (until overcrowded museums eventually decrease the utility for each user) (Izzo 2017; Foà 2019). The financing of club goods through civCF has the disadvantage of possibly increasing inequality within a community, since it generates a payment obligation for civic participation, which not all members of the community might be able to afford (Davies 2015; Hummel 2016).

Civic crowdfunding campaigns for goods which are rivalrous but nonexcludable (termed "commons") can also be within the definition of civCF. An example of a commons good is an outdoor tipi which was financed on Spacehive (Spacehive 2017; Gooch et al. 2020)—there are no access restrictions, but at the same time the tipi can only be used by a limited number of people. The common resource needs to be managed by a central authority, otherwise exploitation of the resource is possible ('free-rider problem'). Civic crowdfunding campaigns can support creating the management structure of commons (Desmoulins and Charbit 2017; Shareable 2018; Catapult 2018).

CivCF is also discussed in the context of so-called digital commons (Ridgway 2015; Bonini and Pais 2017; Carvajal et al. 2012; Rathemacher 
2015), funding access to public non-profit media or public digital archives. However, the term 'commons' is used somewhat misleading in this context, because digital resources are essentially non-rivalrous, as their usage does not reduce the utility for other users. 'Digital commons' might be labelled more precisely 'digital public goods'. Crowdfunding journalism, which is categorized under 'digital commons' projects, often results in semi-excludable goods or club goods. For instance, the German journalism project Krautreporter used civCF to establish an onlinecommunity of readers, which only had access through pre-payment-a 'digital club good' (Vogt and Mitchell 2016; Wenzlaff et al. 2012; Wenzlaff et al. 2013).

The provision of a public good can also be a secondary goal of the crowdfunding campaign (Davies 2014). A crowdfunding campaign for a private good might achieve a general goal in society, such as improving the benefits from using a public good (Hummel 2016). Coming back to examples of media crowdfunding projects such as Krautreporter, DeCorrespondent, or Die Republik, which created a 'digital club good', it could be argued that these projects also contributed to a 'pure' public good: freedom of media.

Using public goods as secondary goals of civCF campaigns would allow to group also projects found on platforms which are dedicated to private goods only. This "Friendraising" or "Friendfunding" (Mattauch 2015) refers to platforms like GoFundMe, which allow crowdfunding campaigns for personal goals, such as health expenses or vacations. These campaigns would not be civCF. At the same time, the platform GoFundMe, which is dedicated to friendraising, is increasingly used for civCF campaigns. A recent example is a campaign to raise funds for the Border Wall of US-President Trump. This campaign by a private individual gathered more than USD $23 \mathrm{~m}$, and tries to establish a public good (a border wall), where the usage is non-excludable (everybody is affected by the border wall) and non-rivalrous (the use of the border wall does not reduce the utility of someone else using the border wall) (Kolfage 2019).

The Trump-Wall is not a friendraising campaign, but a civCF campaign. Since both GoFundMe and Indiegogo belonged to the same company at the campaign beginning, the platform owners should have moved the campaign to Indiegogo and the specific community section if they 
wanted to keep friendraising and civCF separate. Community-based campaigns with a non-personal cause are also excluded from GoFundMe by the terms of the platform (Indiegogo 2019a). They chose not to because of the personal motivation of the project owner, which made a better fit on GoFundMe. But as will be discussed in the "Perspective 4: Platform" section, the choice of platform does not provide a good proxy for the classification as a civCF project.

Acknowledging that many civCF campaigns do not deliver 'pure' public goods, it would be opportune to focus on local public goods-essentially public goods which are focussed in their impact on a specific region (Desmoulins and Charbit 2017; Foà 2019; Boyle 2016). The geographic and demographic scope is relevant for the classification as a civCF campaign (Mayer 2019). CivCF campaigns often have a place-based nature, in the sense that they refer to a specific region or city.

The geographic and demographic scope is relevant for the classification as a civCF campaign (Mayer 2019). CivCF campaigns often have a placebased nature, in the sense that they refer to a specific region or city.

Some civCF campaigns have an action-based temporary nature in a specific region (Brent 2017). The regional focus does not stem from the location of the supporter or the platform, but from the activities carried out in a specific location. One example is the civic crowdfunding project ' $12 / 06 / 2020$ Olympia' which aims to fund a citizen assembly in the Olympic Stadium of Berlin to discuss climate change proposals. This project has an action-based local focus (the assembly in Berlin) and an international public good (combatting climate change) as the campaign goal (Olympia 2020).

The geographic focus of civic crowdfunding campaigns is a central issue in the discussion of the homogeneity of the supporter groups, in the following section. The above example can be tied to the discussion of participation at the beginning of this section-action-based civCF campaigns often have the goal to increase participation in public decisionmaking (Davies 2014; Mayer 2019; Niemeyer et al. 2018; Kusumarani and Zo 2019; European Crowdfunding Network and Passeri 2018; Goodspeed 2019; Porter and Veenswijk 2018).

To summarize, the nature of a civCF project, especially when it comes to the good provided by the project, is still in debate. A public good in 
the strictest sense is undoubtedly in the scope of the definition of civic crowdfunding. Yet researchers broaden the definition by also allowing club goods and commons to be included as a campaign goal in civic crowdfunding, or even include private goods with a secondary public outcome. However, with such a broad definition, almost any crowdfunding campaign can be classified as civCF campaign. Together with the place-based nature of civCF projects and the participatory elements discussed at the beginning of this section, a preliminary definition of civCF through the perspective of the project might be: Civic crowdfunding are campaigns which provide a semi-public good, creating participatory mechanisms with a place-based focus. In the next section, this definition will be enhanced with the perspectives of the supporter.

\section{Perspective 2: Supporter}

The second perspective relates to the supporters of the civic crowdfunding campaign. The nature of crowdfunding entails that especially for donation-based and reward-based crowdfunding, very few restrictions exist for the supporters. If a platform has enabled an international payment system, then theoretically anyone in the world can contribute to a crowdfunding campaign.

In practice, however, civCF campaigns are mostly supported by individuals in the geographic vicinity of the campaign (Mayer 2019; Desmoulins and Charbit 2017). Looping back to the conclusion of the previous section, it should be noted that the place-based nature of the civCF projects, the connection to local participatory mechanisms, and the provision of local semi-public goods make the appeal to local or regional crowds more likely.

Whether an increased homogeneity is connected to the success of a project is still subject to debate. Smaller communities may have a higher success in implementing a project funded through the civCF campaigns (Mayer 2019). A more diverse group has a higher impact because it allows for a wider distribution of the crowdfunding campaign (Davies 2014; Dejean 2019). 
There are few civCF campaigns which appeal to a global audience (Stiver et al. 2015). One example is the unsuccessful campaign to bail out the Greek citizens, which attracted support from all over the globe (Indiegogo 2015). Global civCF campaigns provide a global public good. These campaigns are more difficult to implement through the classic crowdfunding mechanism, but donation-based CFPs serve those who simply want to donate to global causes (Scataglini and Ventresca 2019). Most global donation-based CFPs offer mechanisms to search for campaigns and causes in the vicinity of potential donors, which once again underscores the placed-based nature of civCF (Justgiving 2020).

The local and regional focus of civCF campaigns supports the theory that the interests of supporter groups are more aligned in civCF campaigns than in other campaigns. The self-interest of other crowdfunding campaigns (to receive rewards, obtain shares of companies, or earn interest payments) is replaced by a self-and-other-interest of the supporters (Hummel 2016; Zoellig 2017).

Unlike other forms of crowdfunding, civCF relies less on digital natives and early adopters, seeking new products and services, but instead is characterized by a more extensive mobilization of offline communities (Stiver et al. 2015; Desmoulins and Charbit 2017).

In order to discuss the motives of civCF supporters, this chapter distinguishes the motives of the supporters through three criteria (Desmoulins and Charbit 2017): (1) outcome, (2) action, and (3) communication.

The outcome was already discussed in the previous section. Supporters of civCF campaigns benefit from the provision of the semi-public good (Davies 2014) which is the campaign goal and which supporters can use after the campaign. CivCF campaigns on reward-based CFPs also provide tangible rewards or even payments of interest (Wenzlaff et al. 2015; Hainzer et al. 2014)

The action to support a campaign can by itself be a motivation. The process of mutual awareness of the actions taken by the supporters creates social connectivity between supporters, thus invigorating a community of enablers (van Dijk 2015; Stiver et al. 2015). The emotional returns of participating in the campaign may outweigh the altruistic motive to generate a particular public good (Davies 2015). If the owners of the civic crowdfunding campaign and the supporters of the campaign are based in 
the same community, then the expectations to contribute to the campaign can become peer-pressure-this reciprocal visibility might also outweigh the altruistic motive to generate a particular public good (Hummel 2016; Wenzlaff 2017).

Communication is the third category of analysis in supporters' motivation. Supporters might be motivated to communicate something about themselves when participating in the campaign. This is undoubtedly true for supporters who are not just individual citizens. Private non-profit organizations (Davies 2014), private for-profit organizations and corporations, public organizations (Hummel 2016), and public for-profit organizations (Wenzlaff et al. 2015; Wenzlaff 2017) can also be found as contributors to civic crowdfunding campaigns. For corporate sponsors of a civic crowdfunding campaign as well as for public entities participating in a civic crowdfunding campaign as co-funding partners, the need for the communication of support might be higher than the actual benefit of the public good being generated. As an example, if a local company supports a civic crowdfunding campaign for a playground, the rationale might be more to communicate civic engagement and not using that playground itself.

The literature on civCF lists numerous potential benefits for the supporters (see Table 19.3). In many cases, the initiators of a civic crowdfunding campaign can be found among the group of likely supporters of a campaign cause. Other forms of crowdfunding do not require or even facilitate the fact that supporters and project owners have to be part of the same peer group. In lending-based crowdfunding, for instance, lenders and lendees have quite different economic backgrounds: one has the funds to lend, one seeks the fund to lend. In civic crowdfunding, supporters and project owners share goals of the civic crowdfunding campaign.

The nature of like-mindedness between supporters and initiators is a defining characteristic of civCF campaigns. Therefore, in the next section, the motivations of the project owner will be discussed as well, especially if they are public entities. Expanding the definition of civCF, it should be noted that civCF supporters are usually individual citizens living in close vicinity to the semi-public good, which is the outcome of the civCF campaign. 
Table 19.3 Benefits of civic crowdfunding for supporters

\begin{tabular}{|c|c|}
\hline Benefit for supporters & $\begin{array}{l}\text { Similar benefit } \\
\text { for project } \\
\text { owners (PO)? }\end{array}$ \\
\hline $\begin{array}{l}\text { More transparency, accountability, control of public projects } \\
\text { (Wheat et al. 2013; Stiver et al. 2015; Bone and Baeck 2016) }\end{array}$ & $\begin{array}{l}\text { Yes, if } \mathrm{PO} \text { are } \\
\text { citizens. } \\
\text { No, if } \mathrm{PO} \text { are } \\
\text { city officials. }\end{array}$ \\
\hline $\begin{array}{l}\text { Increased efficiency of public spending (Miglietta and Parisi } \\
\text { 2017) }\end{array}$ & Yes. \\
\hline $\begin{array}{l}\text { Promotes ideals of civic society, combatting political apathy } \\
\text { and supporting self-organization (Hollow 2013) }\end{array}$ & Yes. \\
\hline $\begin{array}{l}\text { Shifts the responsibilities of public spending-it empowers the } \\
\text { citizens to become an active actor in a local environment, } \\
\text { beyond its role as voter or taxpayer (Desmoulins and Charbit } \\
\text { 2017) }\end{array}$ & $\begin{array}{l}\text { Yes, if PO are } \\
\text { citizens. } \\
\text { No, if PO are } \\
\text { city officials. }\end{array}$ \\
\hline $\begin{array}{l}\text { Signals the preferences of citizens towards the government } \\
\text { (Brandmeyer 2015; Zoellig 2017). }\end{array}$ & Yes. \\
\hline $\begin{array}{l}\text { Initiates a public discourse on matters of discontent among } \\
\text { citizens. For instance, discontent can arise from urban } \\
\text { planning outcomes which do not match the preferences of } \\
\text { the citizens (Brandmeyer 2015; Zoellig 2017; van Veelen } \\
\text { 2015; Sedlitzky and Franz 2019; Youngwoo 2019). }\end{array}$ & $\begin{array}{l}\text { Yes, if PO are } \\
\text { citizens. } \\
\text { No, if PO are } \\
\text { city officials. }\end{array}$ \\
\hline $\begin{array}{l}\text { Allows the transformation of public places (Brandmeyer 2015; } \\
\text { Zoellig 2017) }\end{array}$ & Yes. \\
\hline $\begin{array}{l}\text { Allows the reduction of the free-rider problem when } \\
\text { managing common resources (Hummel 2016). }\end{array}$ & Yes. \\
\hline $\begin{array}{l}\text { Increased self-perception of importance and impact of } \\
\text { supporters (Bonini and Pais 2017). }\end{array}$ & Yes. \\
\hline $\begin{array}{l}\text { Enlists citizens as active promoters of their region or city, by } \\
\text { motivating them to share local civic crowdfunding } \\
\text { campaigns in their global network (Cucari and Nuhu 2017) }\end{array}$ & Yes. \\
\hline $\begin{array}{l}\text { Through civic crowdfunding campaigns, self-help groups for } \\
\text { supporters can be established (Miglietta and Parisi 2017). }\end{array}$ & Yes. \\
\hline
\end{tabular}

\section{Perspective 3: Owner}

The third perspective refers to the owners or initiators of a civic crowdfunding campaign. CivCF campaigns are initiated either by citizens or by civic organizations (Hainzer and Stötzer 2013; Davies 2014; Brent 2017; Stiver et al. 2015; Zoellig 2017; Desmoulins and Charbit 2017; Gooch et al. 2020). 
In addition to citizens or civil society organizations, subnational governments, national governments (Zoellig 2017; Desmoulins and Charbit 2017), and public financial institutions (Wenzlaff 2017) are listed as initiators of civCF campaigns. The theoretical discussions of civCF project initiators focusses on the distinction between governmental civCF (with the initiator being a public agency) and community civCF (with the initiator being a citizen or a non-profit created by citizens) (Sedlitzky and Franz 2019). Governmental civCF can provide many benefits to public entities, which is discussed below.

Public entities can use private funds generated through crowdfunding campaigns for projects that need additional private spending (Assenmacher 2017) or face budget cuts, thereby circumventing budget constraints or alleviating fiscal stress (Stiver et al. 2015; Hummel 2016; Miglietta and Parisi 2017). The bridging of budget gaps through civCF campaigns faces criticisms because it can lead to a biased form of public spending, considering only the perspectives of the donors, or reduce the spending available to groups which cannot compensate through private co-financing (Davies 2015).

This criticism is met by the claim that public entities can leverage public spending with private spending (Desmoulins and Charbit 2017), thereby increasing the impact of public spending. The counterargument to the alleged bias claims that private spending co-financing public spending does not necessarily have to be only on matters of interest to the private donor, thereby allowing other citizens to profit from the leveraged public spending as well.

Certainly, civCF campaigns allow public entities to provide services in collaboration with private service providers (Desmoulins and Charbit 2017; Mayer 2019) allowing the co-production of services, which might lead to greater efficiency of the provided services.

Public services can also be screened and tested through civCF campaigns (Miglietta and Parisi 2017), gauging the interest and appeal of proposed public projects to the citizen. Through the civCF campaigns, the public entities can identify grass-root initiatives, civic networks, and stakeholders for public-private partnerships (PPPs) (Zoellig 2017).

To share ownership with citizens can increase the commitment of citizens to improve the maintenance of urban commons. As discussed before, 
this evolving concept of citizenship, whereas the citizen is more than just a taxpayer and voter, is of interest to the supporters, but also of interest to the project owner (Hummel 2016; Desmoulins and Charbit 2017). CivCF can also reduce the Not-In-My-Backyard-Attitude (NIMBY) of citizens being opposed to urban and rural development, by ensuring the "buy-in" of affected citizens (Boyle 2016; Zoellig 2017; Wenzlaff 2017; Goodspeed 2019; Jäckels 2019).

CivCF could simplify decision-making, because the participation in civCF campaigns does not hinge on requirements to be registered to vote or to have formal citizenship status. There is no need to create political parties or non-profit organizations, and civCF campaigns do not stand by definition in juxtaposition to political parties, but it reduces the barriers for the formation of new civic initiatives. The semi-unanimous decision-making in civCF allows spontaneous deliberations of public policy through online platforms, without the efforts and information overload that is connected to participatory budgeting (Hummel 2016; Miglietta and Parisi 2017). At the same time, participatory budget mechanisms in combination with civic crowdfunding might help to make both more attractive for citizens (Lee et al. 2016; Niemeyer et al. 2018).

Civic crowdfunding can support public institutions to achieve a better image, for instance, by promoting efforts to establish an entrepreneurial city (Zoellig 2017) or creating instruments for becoming a Smart City (Miglietta and Parisi 2017; Carè et al. 2018).

Several forms of how public institutions can be involved in civic crowdfunding campaigns have been discussed in the literature (Davies 2014, 2015; Wenzlaff 2017; Bone and Baeck 2016; Bonini and Pais 2017; Passeri 2017; European Crowdfunding Network and Passeri 2018):

- Owner Model: Owning and initiating a civic crowdfunding campaign. For instance, the Istituzione Villa Smeraldi Museo della Civiltà Contadina, which is owned by the municipality of San Marino di Bentivoglio near Bologna, initiated the campaign "\#IlovePomario" on the Italian Platform Ginger to promote a local museum (Ginger and Istituzione Villa Smeraldi Museo della Civiltà Contadina 2016).

- Facilitator Model: Co-Funding civic crowdfunding campaigns by matching grants or loans. On donation-based and reward-based 
platforms, the matching grant is given to successful campaigns, matching each contribution from the supporter. On equity-based platforms, this co-funding takes place through guarantees. For example, in the UK, the city of Newcastle partnered with the lending-based platform FundingCircle to provide loans to local entrepreneurs. (Light and Briggs 2017)

- Selling-Service Model: Supporting civic crowdfunding campaigns by providing services to a civic crowdfunding campaign, for instance, through due-diligence of projects.

- Curator Model: Selecting civic crowdfunding campaigns and promoting them to the communication channels of the public institutions. For instance, the city of Berlin created a meta-platform (City of Berlin 2019), where all projects in Berlin on all platforms were featured. The city also ran a crowdfunding competition which gave prices to the best crowdfunding campaigns in specific branches. The meta-platform also offered consultants the opportunity to present themselves and has an FAQ for crowdfunding supporters. The city did not create its own crowdfunding platform; instead it offered services that supported the development of the regional crowdfunding ecosystem (Beaulieu et al. 2015; Wenzlaff 2019).

- Platform Model: Owning a civic crowdfunding platform. Public authorities are using so-called white-label crowdfunding platforms (Scataglini and Ventresca 2019). A crowdfunding provider operates the platform on behalf of the authorities with logo and the appearance connected to a city or region. In Germany, the first platform of this kind was called "Nordstarter" which was operated by the city of Hamburg. Federal states also partnered with a crowdfunding platform, often through the public state-owned banks (Recke 2019).

In the next section, the perspective of the platform, which hosts the civic crowdfunding campaigns, is discussed. This section established that civCF cannot be defined through citizens as project owners only but has to incorporate public entities as project owner as well.

Notably missing from such a definition are private companies as the initiator or owner of a civCF campaign — even though private companies overwhelmingly are the recipients of funds on reward-, equity-, and 
lending-based CFPs. Bringing back to mind the example of the private brewery ranking first among the list of community campaigns on Indiegogo, it becomes apparent that at least for some platforms, private companies can also run civCF campaigns (Indiegogo 2016).

One of the well-known civCF campaigns initiated by a private company is the LuchtSingel campaign, for funding a bridge in Rotterdam, which was initiated by a private architectural office and raised EUR $4 \mathrm{~m}$ without using a CFP (Wenzlaff 2017; Jäckels 2019; Youngwoo 2019; Pavia 2017; van Veelen 2015). The LuchtSingel project saw significant support from public institutions and private companies, such as the Port of Rotterdam, and is also a prime example of initiating public discourse within the city. Ejecting it from the definition of civCF would be as if ejecting Mickey Mouse from the definition of Disney cartoon characters.

With this in mind, a definition of civCF needs to include the overwhelming majority of citizens and civic institutions acting as project owners. Both elements do not have enough explanatory power to be the sole determinants of a civCF definition. But in combination with the perspective of the supporters and the project goal, it is clear that public institutions play a more significant role in initiating civCF projects than compared to other forms of crowdfunding.

\section{Perspective 4: Platform}

The last perspective to be considered is the functionalities and constraints of the civic crowdfunding platform. The intermediation of platforms is the predominant form of crowdfunding across the globe (Nielsen 2018). Platforms curate and select projects. For instance, the civic crowdfunding platform Voorjebuurt takes up to five working days to verify projects before they are being published on the platform (Voorjebuurt 2019). Platforms also facilitate payments, process withdrawal requests, and complaints (Sedlitzky and Franz 2019), and ensure the compliance with regulation (money laundering, investor protection) (Lehner 2013).

Platforms set the rules for the crowdfunding process, to which the projects and the project owners have to adhere. Platforms set the rules for the minimum and the maximum contribution, which has an impact on 
the type of participation that the platforms allow. Ensuring that small contributions are also possible has a significant impact on the participatory culture of civic crowdfunding (Bonini and Pais 2017).

Platforms also determine the mechanism of success of crowdfunding. The two popular models are the All-or-Nothing model or the Keep-It-All model. In All-or-Nothing campaigns, funds have to reach a pre-set threshold before transferred to the project owner. This model is associated with many reward-based crowdfunding platforms, such as Kickstarter.

The Keep-It-All model does not require a threshold—funds are transferred to the project owner regardless if the target sum of the campaign is reached or not. The Keep-It-All model is often associated with donationbased crowdfunding platforms (Paredes et al. 2018), such as the German platform Betterplace or the friendraising platform GoFundMe.

Some platforms employ both models for structuring crowdfunding campaigns. The US-based platform Indiegogo allows a Keep-It-All model called flexible funding, but also an All-or-Nothing model called Fixed Funding. Spacehive is a civic crowdfunding platform based in the UK and employs the All-or-Nothing model. Goteo, on the other hand, employs the Keep-It-All model (Goteo 2019b; Spacehive 2019; Indiegogo 2019a).

The model used for civic crowdfunding platforms has an enormous impact on the civic crowdfunding projects. Trust in the platform translates into trust into projects (Moysidou and Hausberg 2019). Out of concerns for their reputation, platforms ensure that the projects are feasible. The All-or-Nothing model forces projects to make a realistic calculation of the target sum. The Keep-It-All model allows civCF campaigns to use the funds contributed by the supporters even if a target goal is not reached, thus eliminating the risk of a failed campaign.

The platform asks projects to provide documents about the feasibility of the campaign goal. This allows them eliminating projects that are deemed as unfeasible or unserious (curation). Platforms also choose how visible individual projects are (Davies 2014) by promoting them through social media or newsletters (promotion).

It would not be prudent to define a civic crowdfunding platform only as a subset of donation-based or reward-based crowdfunding (Sedlitzky 
and Franz 2019), since equity-based crowdfunding (i.e. investments in renewable energy infrastructure), and lending-based crowdfunding (i.e. loans to municipalities) are increasingly popular (Hainzer et al. 2014; Wenzlaff et al. 2015; Bone and Baeck 2016; Assenmacher 2017; Old et al. 2019).

One obvious criterion to define civCF platforms would be selflabelling. Platforms like Spacehive, Voorjebuurt, Goteo, or Place2Help use the label 'Civic Crowdfunding' actively. Other platforms, such as Startnext, Visionbakery, or Indiegogo, have project categories dedicated to civic projects or community projects.

The second criterion to position a platform within civCF would be functionalities that include the participation of citizens through nonfinancial contributions, such as volunteering or voting (Wenzlaff 2017; Desmoulins and Charbit 2017). For instance, the civic crowdfunding platform Spacehive allows projects to create so-called Wishlists-crowdfunding campaigns can ask for non-financial contributions (Chant and Spacehive 2019). Platforms that are not active in civCF restrict the platform functionalities to financial contributions and comments.

The third criterion to position a platform within civic crowdfunding can be the nature of its business model and the owner of the platform. Both issues are closely related. Private companies own platforms like Voorjebuurt or Spacehive; private non-profit foundations own platforms like Goteo (Goteo 2019a, b; Chant and Spacehive 2019; Spacehive 2019; Voorjebuurt 2019). In both models, the platforms earn income through fees paid by the project owners, often only in the case of a successful campaign. Several fee models exist, such as fixed-fee models, variable-fee models, or voluntary-fee models. However, there are civCF platforms which do not have any fees, not even for the processing of payments. Often these "free" platforms are maintained and operated by a public entity or a private entity with a public purpose (Wenzlaff 2017).

The platform is critical to define civic crowdfunding. By self-labelling, creating distinct project categories, or developing functionalities to involve citizens, projects are attracted to the platform with a specific purpose. These civic projects are reaching out to supporters with a specific mindset, such as contributing to a campaign which has a civic goal, for instance, by creating a semi-public good within a specific region. By 
doing so, the platforms create a semi-public good in themselves by providing a 'non-material digital infrastructure' which aligns interests of supporters, project owners, and platform providers. Infrastructure is defined as a public good which expands economics opportunities of individual agents through network effects and economies of scale (Buhr 2003; Kasper 2015; Torrisi 2009). The platform provides a technical infrastructure (hosting projects, processing payments), an organizational infrastructure (turning abstract ideas into concrete projects) and a social infrastructure (initiating public debates around civic purposes) (Davies 2014; Nielsen 2018; Logue and Grimes 2019).

It is crucial to keep in mind that the idea of a social-organizationaltechnical infrastructure provided by a platform is not unique to civCF or crowdfunding in general. Any 'digital' platform can be analysed through this perspective of 'non-material digital infrastructure'. It helps, however, to understand that the platform is central to connecting the three other perspectives in civCF campaign and creating a narrative around the civCF campaigns (Porter and Veenswijk 2018; Lee et al. 2016).

It is also essential to consider that the social-organizational-technical infrastructure can also be provided through the website of the project initiator themselves. The website then becomes a 'one-project'-platform. The missing opportunities for scaling effects and the missing independence for validation, selection, and curation of projects are counterbalanced by the alignment of interests of supporters and the project initiators.

The fourth perspective of the platform makes it necessary to expand the definition of civCF by considering the central function of the platform, as described above, which will be done in the final section.

\section{Conclusion}

The previous sections have discussed four perspectives of civic crowdfunding. The section on the project perspective has shown that civCF projects have three distinguishing features: contribute to political participation, provide a semi-public good, and have a place-based nature. The section on the supporters has shown that the geographic vicinity of supporters creates like-mindedness between supporters and project 
initiators, which as can be seen in the "Definition and Perspectives of Civic Crowdfunding" section on the project owners makes it attractive for public institutions to become project owners. The diversity of benefits obtained by supporters through civic crowdfunding campaigns are beyond the personal benefits of other types of crowdfunding. The "Perspective 1: Project" section has shown that the platforms have a central role in defining the relationship between supporters and owners and determining the impact of the public good generated by the campaign. The "Perspective 1: Project" section also discussed the notion of the platform being a public good, which is more prevailing in civic crowdfunding than in other types of crowdfunding.

The four perspectives in the previous sections motivate this chapter to revise the classic definition of crowdfunding: "Crowdfunding is an open call, essentially through the Internet, for the provision of financial resources either in the form of donation or in exchange for some form of reward andlor voting rights in order to support initiatives for specific purposes" (Belleflamme et al., 2014).

In the context of civic crowdfunding, this chapter rephrases the definition by including the purpose, the interaction between supporters and owners, and the platform: "Civic crowdfunding is an open call, essentially through the internet, for the provision of financial resources to produce placebased semi-public goods with a collaborative and coordinated response by the financial supporters. The civic crowdfunding platform is defined by its aim to facilitate both collaboration and coordination to maintain or improve the public good aimed at by the civic crowdfunding campaign".

The argument for a revised definition of civic crowdfunding stems from the belief that crowdfunding is more than just the platform, the projects, the project owners, and the supporters. Like many other technological innovations, the practice of crowdfunding creates an ecosystem of services and products, such as networks of consultants, online tools, education opportunities, evaluation methods (Wenzlaff 2017, 2019).

This chapter argues that research in civic crowdfunding should focus more on the specific role that civCF platforms play in the facilitation of projects and how they interact with public institutions. This analysis entails how public support mechanisms can enhance the provision of well-maintained socio-organizational-technical infrastructure. 
A research agenda for civic crowdfunding should start with the interaction between special-purpose civCF CFPs and civCF categories on allpurpose CFPs, proceed with segmenting data from the all-purpose CFPs, and analyse success factors in civCF campaigns, especially how they are different from more commercially-oriented entrepreneurial campaigns. Since platforms play such a central role, it would be instructive to analyse the attitudes of both project owners and supporters towards the platforms, primarily if a public entity maintains the platform. Finally, it would help to analyse the implementation of civCF projects, to understand better whether civCF projects are only short-term responses to funding gaps, or can create long-term organizational structures which continue to provide and manage public goods. This could inform the debate on whether civCF erects new barriers to political participation or creates new avenues for citizens to interact with public authorities.

The depth of civic crowdfunding research is increasing (Wenzlaff 2020), with case studies focussing on non-Anglo-American markets being published. Nevertheless, very few cross-country comparisons exist. Given the place-based nature of civCF, the (implicit) assumption that civCF is similar in each country and region needs to be examined critically.

Such an analysis would allow both platforms and public authorities to develop better mechanisms for aligning public budgets and civic crowdfunding campaigns through support mechanisms. Since civCF campaigns are still small compared to other forms of crowdfunding, the outlined research agenda could provide public decision-makers with information on how to design support mechanism to create campaigns of greater volume and possibly more impact. It could also inform the project owners of civCF campaigns whether to focus their efforts on local, regional, or global audiences. Most importantly, the analysis could help project owners identify the right platform and shape their campaign in such a way that the audience relates to the benefits for themselves as well as the benefits for the wider community, which would result in improved semi-public goods provided by crowdfunding. 
Acknowledgements The author would like to thank Prof Dr Sebastian Späth, Prof Dr Ivana Pais, Dr Krystallia Moysidou, Prof Dr Piet Hausberg, Prof Dr Rotem Shneor, and two anonymous reviewers for their valuable feedback.

\section{References}

Assenmacher, K. (2017). Crowdfunding als kommunale Finanzierungsalternative. Wiesbaden: Springer Gabler.

Barollo, A., \& Castrataro, D. (2013). Il Crowdfunding Civico: Una Proposta. Retrieved from https://issuu.com/alessiobarollo/docs/civic-crowdfunding.

Beaulieu, T., Sarker, S., \& Sarker, S. (2015). A Conceptual Framework for Understanding Crowdfunding. Communications of the Association for Information Systems, 37, 1-31.

Belleflamme, P., Lambert, T., \& Schwienbacher, A. (2014). Crowdfunding: Tapping the Right Crowd. Journal of Business Venturing, 29(5), 585-609.

Bone, J., \& Baeck, P. (2016). Crowdfunding Good Causes. Retrieved from https://www.nesta.org.uk/sites/default/files/crowdfunding_good_ causes-2016.pdf.

Bonini, T., \& Pais, I. (2017). Hacking Public Service Media Funding: A Scenario for Rethinking the License Fee as a Form of Civic Crowdfunding. International Journal on Media Management, 19(2), 123-143.

Boyle, T. M. (2016). The City and the Crowd:An Exploration of Civic Crowdfunding Disruption to Local Government Led City Planning and the Quest to Co-create Liveability. Master Thesis. Biddeford, ME: University of New England.

Brandmeyer, O. (2015). Crowdfunding Urbanism-Schwarmfinanzierung in Der Stadtentwicklung. Technische Universität Berlin, Institut für Stadt- und Regionalplanung.

Brent, D. A. (2017). The Geography of Civic Crowdfunding: Implications for Social Inequality and Donor-project Dynamics. Working Paper 2017-09, Department of Economics Louisiana State University.

Buhr, W. (2003). What is Infrastructure?VolkswirtschaftlicheDiskussionsbeiträge. Universität Siegen, Fakultät Wirtschaftswissenschaften, Wirtschaftsinformatik und Wirtschaftsrecht. Retrieved from https:/econpapers.repec.org/paper/ siesiegen/107-03.htm.

Carè, S., Trotta, A., Carè, R., et al. (2018). Crowdfunding for the Development of Smart Cities. Business Horizons, 61(4), 501-509. 
Carvajal, M., García-Avilés, J. A., \& González, J. L. (2012). Crowdfunding and Non-profit Media. Journalism Practice, 6(5-6), 638-647.

Catapult. (2018). Civic Crowdfunding-A Guidebook for Local Authorities. Retrieved from http://futurecities.catapult.org.uk/resource/civic-crowd funding-guidebook-local-authorities/.

Chant, J., \& Spacehive. (2019). FAQs. Retrieved from https://about.spacehive. $\mathrm{com} / \mathrm{faqs} /$.

City of Berlin. (2019). Crowdfunding Berlin. Retrieved from https://www. crowdfunding-berlin.com/en/.

Colasanti, N., Frondizi, R., \& Meneguzzo, M. (2018). Higher Education and Stakeholders' Donations: Successful Civic Crowdfunding in an Italian University. Public Money \& Management, 38(4), 281-288.

Cucari, N., \& Nuhu, K. (2017). Co-Creation of Value in Relationships Crowdfunding-territory: An Exploratory Study in the Italian Context. Paper present at the European Conference on Intangibles and Intellectual Capital, Academic Conferences International Limited, Kidmore End, UK.

Damle, S., Moti, M. H., Chandra, P., \& Gujar, S. (2019). Aggregating Citizen Preferences for Public Projects Through Civic Crowdfunding. In Proceedings of the 18th International Conference on Autonomous Agents and MultiAgent Systems.

Davies, R. (2014). Civic Crowdfunding: Participatory Communities, Entrepreneurs and the Political Economy of Place. Master Thesis, Massachusetts Institute of Technology. Retrieved from https://dspace.mit.edu/bitstream/handle/1721.1/ 89954/890127961-MIT.pdf?sequence=2.

Davies, R. (2015). Three Provocations for Civic Crowdfunding. Information, Communication \& Society, 18(3), 342-355.

Dejean, S. (2019). The Role of Distance and Social Networks in the Geography of Crowdfunding: Evidence from France. Regional Studies, 54(3), 329-339.

Desmoulins, G., \& Charbit, C. (2017). Civic Crowdfunding: A Collective Option for Local Public. OECD Regional Development Working Papers 2017/02.

Dijk, C. (2015). How Communities Make Crowdfunding Campaigns More Successful: Research into the Success of Crowdfunding Communities and Considerations Towards a Successful Crowdfunding Campaign. Retrieved from http://dare.uva.nl/document/605860.

Doan, M. A., \& Toledano, M. (2018). Beyond Organization-centred Public Relations: Collective Action through a Civic Crowdfunding Campaign. Public Relations Review, 44(1), 37-46. 
Einhörnchen. (2015). Einhorn. Startnext.com. Retrieved from https://www. startnext.com/einhorn.

European Crowdfunding Network. (2018). Triggering Participation-A Collection of Civic Crowdfunding and Match-funding Experiences in the EU. Brussels: European Crowdfunding Network.

Foà, C. (2019). Crowdfunding Cultural Projects and Networking the Value Creation: Experience Economy between Global Platforms and Local Communities. Arts and the Market, 9(2), 235-254.

Förderkreis des FEZ-Berlin e.V. (2018). FEZ-Berlin Brunnen. Startnext.com. Retrieved from https://www.startnext.com/fez-berlin-brunnen.

Ginger. (2016). \#ILOVEPOMARIO. Retrieved from https://www.ideaginger. it:443/progetti/ilovepomario.html\%27.

Gooch, D., Kelly, R. M., Stiver, A., et al. (2020). The Benefits and Challenges of Using Crowdfunding to Facilitate Community-led projects in the Context of Digital Civics. International Journal of Human-Computer Studies, 134, 33-43.

Goteo Fundación. (2019a). Donar. Goteo.Org. Retrieved from http://en.goteo. org/donate.

Goteo Fundación. (2019b). Goteo.Org: Crowdfunding the Commons. Goteo. Org. Retrieved from http://en.goteo.org/

Hainzer, M., \& Stötzer, S. (2013). Crowdfunding Für Nonprofit-Organisationen. Fachzeitschrift Für Verbands- Und Nonprofit-Management, 39(2), 38-46.

Hainzer, M., Stötzer, S., \& Ellmer, M. (2014). Crowdfunding-Basierte Bürgerkreditmodelle in Kommunen. Zeitschrift Für Öffentliche Und Gemeinwirtschaftliche Unternehmen, 37(1-2), 54-72.

Hollow, M. (2013). Crowdfunding and Civic Society in Europe: A Profitable Partnership? Retrieved from https://papers.ssrn.com/sol3/papers.cfm? abstract_id=2333635.

Hummel, D. (2016). Civic Crowd-funding: A Potential Test of the Voluntary Theory of Public Finance For Public Capital Goods. Journal of Public Budgeting, Accounting \& Financial Management, 28(2), 171-195.

Indiegogo. (2012). Restore the Shore. Indiegogo. Retrieved from http://www. indiegogo.com/restore-the-shore.

Indiegogo. (2015). Greek Bailout Fund. Indiegogo. Retrieved from https://www. indiegogo.com/projects/1324990.

Indiegogo. (2016). Stone Groundbreaking Collaborations. Indiegogo. Retrieved from http://www.indiegogo.com/projects/838279/fblk. 
Indiegogo. (2019a). Is My Campaign Allowed on Indiegogo? Indiegogo Help Center. Retrieved from http://support.indiegogo.com/hc/en-us/articles/ 360000574528-Is-My-Campaign-Allowed-on-Indiegogo-.

Indiegogo. (2019b). Support Community Projects at Indiegogo. Indiegogo. Retrieved from https://www.indiegogo.com/explore/community-projects? project_type=campaign\&project_timing=all\&sort=most_funded.

Izzo, M. (2017). Stakeholders and Museum Crowdfunding. Modern Economy, $8(4), 518-530$.

Jäckels, M. (2019). Civic Crowdfunding. In U. Altrock, D. Kurth, R. Kunze, H. Schmidt, \& G. Schmitt (Eds.), Programmatik der Stadterneuerung: Jahrbuch Stadterneuerung 2019 (pp. 73-95). Wiesbaden: Springer Fachmedien.

Justgiving. (2020). JustGiving. Retrieved from https://www.justgiving.com/ crowdfunding.

Kasper, R. (2015). A Definition for Infrastructure-Characteristics and Their Impact on Firms Active in Infrastructure. Technische Universität München. Retrieved from https://d-nb.info/1071370057/34.

Kolfage, B. (2019). We the People Will Build the Wall. Gofundme.Com. Retrieved from https://www.gofundme.com/TheTrumpWall.

Kukla, L. (2014). Stadt- Und Regionalentwicklung 2.0-Crowdfunding Als Kommunales Förderinstrument. Universität Eichstätt.

Kusumarani, R., \& Zo, H. (2019). Why People Participate in Online Political Crowdfunding: A Civic Voluntarism Perspective. Telematics and Informatics, 41, 168-181.

Lee, C. H., Bian, Y., Karaouzene, R., \& Suleiman, N. (2019). Examining the role of narratives in civic crowdfunding: linguistic style and message substance. Industrial Management \& Data Systems, Vol. ahead-of-print No. ahead-of-print. https://doi.org/10.1108/IMDS-08-2018-0370.

Lee, C. H., Zhao, J. L., \& Hassna, G. (2016). Government-incentivized Crowdfunding for One-belt, One-road Enterprises: Design and Research Issues. Financial Innovation, 2(1), 1-14.

Lehner, O. M. (2013). Crowdfunding Social Ventures: A Model and Research Agenda. Venture Capital, 15(4), 289-311.

LeihDeinerStadtGeld GmbH. (2012). Investment Investition in Freiwillige Feuerwehr. Retrieved from https://www.leihdeinerstadtgeld.de/oestrichwinkel. 
Light, A., \& Briggs, J. (2017). Crowdfunding Platforms and the Design of Paying Publics. In Proceedings of the 2017 CHI Conference on Human Factors in Computing Systems. Denver, Colorado, USA: ACM Press, pp. 797-809.

Logue, D., \& Grimes, M. (2019). Platforms for the people: Enabling civic crowdfunding through the cultivation of institutional infrastructure. Strat. Mgmt. J, 1-31. https://doi.org/10.1002/smj.3110.

Mattauch, C. (2015). Coole Kohle. Liberal Magazin.

Mayer, M. (2019). Examining Community Dynamics of Civic Crowdfunding Participation. Computer Supported Cooperative Work, 28(5), 961-975.

Miglietta, A., \& Parisi, E. (2017). Civic Crowdfunding: Sharing Economy Financial Opportunity to Smart Cities. In E. R. Sanseverino, R. R. Sanseverino, \& V. Vaccaro (Eds.), Smart Cities Atlas (pp. 159-172). Cham: Springer International Publishing.

Moysidou, K., \& J. Piet Hausberg, J. P. (2020). In crowdfunding we trust: A trust-building model in lending crowdfunding. Journal of Small Business Management, 58(3), 511-543. https://doi.org/10.1080/00472778.2019. 1661682.

Nielsen, K. R. (2018). Crowdfunding through a Partial Organization Lens-The Co-dependent Organization. European Management Journal, 36(6), 695-707.

Niemeyer, C., Teubner, T., Hall, M., et al. (2018). The Impact of Dynamic Feedback and Personal Budgets on Arousal and Funding Behaviour in Participatory Budgeting. Group Decision and Negotiation, 27(4), 611-663.

Old, R., Boyle, D., Baeck, P., \& Bone, J. (2019). Taking Ownership: Community Empowerment through Crowdfunded Investment. London: Nesta. Retrieved from https://media.nesta.org.uk/documents/Taking_ownership_v4.pdf.

Oliva, N. (2018). Crowdfunding and Civic Crowdfunding: Theoretical Features and Future Prospects. In U. Comite (Ed.), Public Management and Administration (pp. 115-126). London: IntechOpen.

Olympia. (2020). 12/06/2020-Ermögliche mit uns das größte Demokratie Festival. Startnext.com. Retrieved from https://www.startnext.com/12062020. Onwuegbuzie, A. J., \& Frels, R. (2016). Seven Steps to a Comprehensive Literature Review: A Multimodal \& Cultural Approach. Los Angeles: SAGE.

Paredes, H., Barroso, J., \& Bigham, J. P. (2018). All (of us) Can Help: Inclusive Crowdfunding Research Trends and Future Challenges. Paper Presented at the IEEE 22nd International Conference on Computer Supported Cooperative Work in Design. Nanjing, China.

Passeri, F. (2017). The European Dimension of Civic Crowdfunding. Brussels: European Crowdfunding Network. 
Pavia, L. (2017). Dalla Do It Yourself (DIY) alla Do It Together (DIT) Strategy: la campagna di crowdfunding "I Make Rotterdam" per la realizzazione del ponte Luchtsingel a Rotterdam in Olanda. La città creative, pp. 187-195.

PGS-Team. (2018). Pacific Garbage Screening. Startnext.com. Retrieved from https://www.startnext.com/pgs.

Porter, A. J., \& Veenswijk, M. (2018). Narrative "End States" and the Dynamics of Participation in Civic Crowdfunding. International Journal of Communication, 12, 2367-2386.

Rathemacher, A. (2015). Crowdfunding Access to Archives. Library Journal, 140(2), 43.

Recke, M. P. (2019). Hamburg's Entrepreneurial Ecosystem and the Next Media Initiative: Public Policy Towards Entrepreneurship. epubli.

Ridgway, R. (2015). Crowdfunding the Commons? In G. Lovink, N. Tkacz, \& P. De Vries (Eds.), Moneylab reader (pp. 281-294). Amsterdam: Institute of Network Cultures.

Samuelson, P. A. (1954). The Pure Theory of Public Expenditure. The Review of Economics and Statistics, 36(4), 387-389.

Scataglini, M., \& Ventresca, M. J. (2019). Funding the UN Sustainable Development Goals: Lessons from Donation-based Crowdfunding Platforms. Saïd Business School WP 2019-03. Retrieved from https://ssrn.com/ abstract $=3328731$.

Sedlitzky, R., \& Franz, Y. (2019). What if We All Chip In? Civic Crowdfunding as Alternative Financing for Urban Development Projects. Built Environment, 45(1), 26-44.

Shareable. (2018). Sharing Cities: Activating the Urban Commons. Tides Center/ Shareable.

Simeoni, F., \& De Crescenzo, V. (2018). Ecomuseums (on Clean Energy), Cycle Tourism and Civic Crowdfunding: A New Match for Sustainability? Sustainability, 10(3), 817.

Spacehive. (2017). Learning Tree Tipi and Super Storage! Retrieved from https:// wwww.spacehive.com/learning-tree-tipi-and-super-storage.

Spacehive. (2019). Spacehive-Crowdfunding for Local Projects. Retrieved from https://www.spacehive.com/

Stiver, A., Barroca, L., Petre, M., Richards, M., \& Roberts, D. (2015). Civic Crowdfunding: How Do Offline Communities Engage Online? In Proceedings of the 2015 British HCI Conference, pp. 37-45. 
Torrisi, G. (2009). Public Infrastructure: Definition, Classification and Measurement Issues. Economics, Management, and Financial Markets, $4(3), 100-124$.

Veelen, T. (2015). Civic Crowdfunding: A Financial Kickstart to Urban Area Development? An Analysis of the Institutional Structure in Which Civic Crowdfunding in Urban Area. Retrieved from http://repository.tudelft.nl/ assets/uuid:bf8caf4f-79a8-4257-ac88-948518f5cc36/Thesis_Tim_van_ Veelen_FINAL.pdf.

Vogt, N., \& Mitchell, A. (2016). Crowdfunded Journalism: A Small but Growing Addition to Publicly Driven Journalism. Pew Research Center's Journalism Project (blog). January 20. Retrieved from http://www.journalism. org/2016/01/20/crowdfunded-journalism/.

Voorjebuurt. (2019). Terms and Conditions. Retrieved from https://voorjebuurt.nl/en/pages/terms-and-conditions.

Wenzlaff, K. (2017). Civic Crowdfunding_Finanzierung von Öffentlichen Gütern. In H. Pechlaner \& X. Poppe (Eds.), Crowd Entrepreneurship: Das Gründungsgeschehen Im Wandel (pp. 215-230). Wiesbaden: Springer Gabler. Wenzlaff, K. (2019). Developing a Policy Framework for Emerging Crowdfunding Ecosystems. ORF Policy Briefs, No. 302. New Delhi: Observer Research Foundation.

Wenzlaff, K. (2020). Civic Crowdfunding-Overview of the Literature and Contribution to Academic Debate.

Wenzlaff, K., El Mallouki, J., \& Partale, A. (2015). Civic Crowdfunding-Wie Crowdfunding Die Stadt Verändert Und Welche Potenziale Das Neue Finanzierungsinstrument Für Städte Und Regionen Hat. AWV-Informationen, No. 2, March/April 2015. Retrieved from http://www.awv-net.de/publikationen/awv-informationen/2015/info-2-2014-kopie.html.

Wenzlaff, K., Hoffmann, A., \& Pachali, D. (2012). Freiwillig Bezahlen? Crowdfunding Und Social Payment Im Journalismus. In D. Pachali (Ed.), Öffentlichkeit Im Wandel: Medien, Internet, Journalismus (pp. 82-87). Berlin: Heinrich-Böll-Stiftung.

Wenzlaff, K., Kramp, L., Novy, L., \& Ballwieser, D. (2013). Journalismus in Der Digitalen Moderne: Einsichten—Ansichten—Aussichten. Wiesbaden: Springer VS. Wheat, R. E., Wang, Y., Byrnes, J. E., et al. (2013). Raising Money for Scientific Research Through Crowdfunding. Trends in Ecology \& Evolution, 28(2), 71-72. 
Youngwoo, J. (2019). Building Your City Through Crowdfunding-Rotterdam's "Luchtsingel". Social Life. Retrieved from http://www.social-life.co/blog/ post/Crowdfunding/.

Zhang, Q., Li, L., Niu Q., \& Yu, Y. (2019). How should Civic Crowdfunding Lead China's Home-Based Care Service for the Elderly out of the Financial Shortage? Environmental Analysis of Four Practical Patterns with the Theory of Funding Ecosystem. Ekoloji, 28(107), 4197-4204.

Zoellig, R. (2017). Die Relevanz von Civic Crowdfunding Als Kommunales Finanzierungs-Sowie Beteiligungsinstrument in DerDeutschen Stadtentwicklung. Master Thesis. Münster: Westphalia Wilhelms University, Institute of Geography.

Open Access This chapter is licensed under the terms of the Creative Commons Attribution 4.0 International License (http://creativecommons.org/licenses/ by/4.0/), which permits use, sharing, adaptation, distribution and reproduction in any medium or format, as long as you give appropriate credit to the original author(s) and the source, provide a link to the Creative Commons licence and indicate if changes were made.

The images or other third party material in this chapter are included in the chapter's Creative Commons licence, unless indicated otherwise in a credit line to the material. If material is not included in the chapter's Creative Commons licence and your intended use is not permitted by statutory regulation or exceeds the permitted use, you will need to obtain permission directly from the copyright holder.

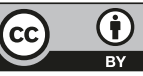

